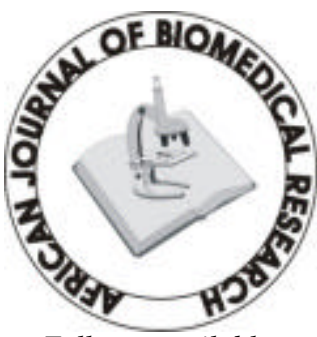

Full-text available at http://www.ajbrui.com http://www.bioline.br/md http://www.ajol.com

Received:

December 2006

Accepted (Revised) : May 2007

Published

September 2007
Short communication

\section{Antimutagenic and Potential Anticarcinogenic Activities of Aloe-Vera Gel and Aqueous Garlic Extract in the Bacterial Reverse Mutation Test (Ames Assay)}

\section{Ogunjobi A. A., Fagade O. E and David O. O.}

Environmental Microbiology and Biotechnology Unit, Department of Botany and Microbiology

University of Ibadan, Ibadan

\section{ABSTRACT}

The study was carried out to verify the potential anticarcinogenic and antimutagenic activity of garlic and aloe-vera. The ability of aqueous garlic extract and Aloe-Vera gel to inhibit mutation in tester strain of Escherichia coli WP2 uvrA was determined in this study. (The tester E. coli tryptophan auxotroph strain was obtained from Yale University U.S.A.). The spontaneous mutation rate of $E$. coli WP 2 uvrA was determined in the Ames assay to be $2.2 \times 10^{-7}$. The acridine mutagen showed $333.8 \%$ increase of spontaneously reverting colonies of the tester strain. Different concentrations of aqueous garlic extract and aloe-vera gel conferred varying degrees of antimutagenic activities on the tester E. coli WP2 uvrA. Aqueous garlic extract was found to have its highest antimutagenic activity at a concentration of $0.5 \mathrm{~g} / \mathrm{cm}^{3}$ (the highest concentration tested) with $81.02 \%$ reduction in revertant colonies were observed. $0.1 \mathrm{~g} / \mathrm{cm}^{-3}$ and $0.25 \mathrm{~g} / \mathrm{cm}^{-3}$ garlic extract produced $72.16 \%$ and $74.82 \%$ reduction of revertant colonies respectively. Aloe-Vera gel produced $43.6 \%, 37.2 \%$ and $33.68 \%$ reduction in revertant colonies at concentration of $0.5 \mathrm{ml}, 0.2 \mathrm{ml}$ and $0.1 \mathrm{ml}$ per plate of the E. coli respectively. From the result obtained in this study, garlic has tremendous potential antimutagenic and anticarcinogenic substances..

(Afr. J. Biomed. Res. 10: 275 - 278)

Key words : - Oreochromis niloticus, infection, Clinostonum tilapiae, histopathology

*Address for Correspondence: e-mail: aaogunjobi@ hotmail.com 


\section{INTRODUCTION}

Cancer (Latin Cancer, Crab) is a disease or disorder in which a single normal body cell undergoes genetic transformation into a cancer cell and will begin to reproduce uncontrollable (Varmus and Weinberg, 1993). There is a high correlation between carcinogencity and mutagenicity. Ninety percent (i.e., 156/174) of the carcinogens tested were found to be mutagenic in the Ames assay (McCann et. al, 1975b). Recently, considerable attention has been focused on identifying naturally occurring chemo-preventing substances capable of inhibiting, retarding or reversing the multistage carcinogenesis (usually initiated by mutation) (Surh, 1999).

Garlic (Allium sativum) is one of the most popular spices in the world and it has been reported to contain a powerful natural antibiotic stronger than penicillin and tetracycline (Adetumbi and Lau, 1983). Aloe vera (Aloe barbadensis mill) has been reported to provide unique benefit to human body. Some of these benefits are its deep penetration of the body tissue, antiseptic effects, stimulation of cell growth, nerve settling and detoxification of the human body cell (Haller, 1990). Since a wealth of the advantages mentioned above occur in garlic and Aloe vera gel, an assay of the antimutagenic activity of these two plant extracts was the focus of this study.

Therefore, the objectives of this research was to use the bacteria reverse mutation test (the Ames test) to determine the spontaneous mutation rate of the E.coli WPA uvrA strain, to determine the level of mutagenicty of Acridine mutagen to $E$. coli WP2 uvrA. Also, to assay the antimutagenic activity of Aloe vera gel and garlic aqueous extract.

\section{MATERIALS AND METHODS}

The two plant samples used in this study (Garlic bulbs) were purchased at the Oke-odo market in the Ifako-Ijaye area of Lagos state while the Aloe vera plant were obtained from a private garden at Ogba Lagos state. The plants materials were certified in the herbarium of the Department of Botany and Microbiology, University of Ibadan.
The tester (mutant) strain used is the Escherichia coli Tryptophan auxotroph strain, E. coli WP2 uvrA. It is one of the several strain suggested by Ames et al., (1973) for use in the bacterial reverse mutation assay. It was obtained from the E. coli Genetic Stoc Centers, MCD Biology Department, Yale University, New Haven, Connecticut, U.S.A. It has a strain designation of WP2 uvrA and E. coli Genetic stock centre designation of CGSC \#5379. This strain carries a mutation of an E. coli B gene with the following chromosomal markers. Lon-II, Sul A1, trpE 65(OC) and uvrA 155.

Garlic bulbs were peeled and oven dried. The dried bulbs were blended into fine powder using a seed and nut grinder. Fifty grams of powdered garlic sample was dissolved in $250 \mathrm{~cm}^{3}$ of hot distilled water and was continuously stirred for about 20 minutes. This was left standing for 24 hours in a corked conical flask. The extract was obtained by sieving the garlic and water mixture (after 24 hours) with a net sieve. Filtration was repeated using a whatman No.4 filter paper. The filtrate obtained was freezed dried at $-72^{\circ} \mathrm{C}$ using an Edwards Modulyo (FDII) freezer drier.

During, analysis, a known weight of garlic powder was dissolved in distilled water and the solution was filter sterilized using a $0.2 \mu \mathrm{m}$ Millipore filter. Aloe-Vera gel was obtained by peeling the green epidermal layer of the leaf. The succulent parenchyma tissue obtained were liquidized using Phillip blender at ultra high speed. No water was added, the resultant gel was filter sterilized using $0.2 \mu \mathrm{m}$ filter. The gel was thereafter stored in a sterile bottle. Sterility test of the two plant extracts was carried out before use.

All the media used were prepared according to the method of Maron and Ames (1983).

Spontaneous Mutation Rate of E. coli WP2uvrA: A drop of broth culture was aseptically spread over the plates of minimal glucose plate with glass spreader. The plates were incubated at $37{ }^{\circ} \mathrm{C}$ and the E. coli that was able to growth (has been spontaneously mutated) were counted after 24 hours.

Mutagenic Activity of Acridine Orange: The mutagenic activity of acridine orange was tested at 
2 concentrations; $100 \mu \mathrm{g} /$ plate and $50 \mu \mathrm{g} /$ plate. $1 \mathrm{mg} / \mathrm{ml}$ of the acridine orange was prepared with sterile distilled water and filter sterilized using $0.2 \mu \mathrm{m}$ hydrophobic membrane filter. This was diluted with sterile distilled water to $100 \mu \mathrm{g} / \mathrm{ml}$ and $50 \mu \mathrm{g} / \mathrm{ml}$. $0.1 \mathrm{ml}$ of the mutagen and $0.1 \mathrm{ml}$ of the broth culture of the bacteria were added to $2 \mathrm{mls}$ of molten tryptophan-top agar in the test tubes. Each tube was briefly vortex for 4 second before pouring on a minimal glucose agar plates. A control containing sterile distilled water in place of tryptophan in the top agar was set up along. The tryptophan-top agar contained $100 \mathrm{ml}$ of top agar and $10 \mathrm{ml}$ of $0.5 \mathrm{nM}$ of tryptophan dispensed in $2 \mathrm{ml}$ quantities in test tubes. The plates were incubated after the top agar had solidified at $37^{\circ} \mathrm{C}$ for 48 hours. The revertant colonies were counted thereafter.

Antimutagenic Activity of Plant Extract: Antimutagenic activity of the samples were assayed at different concentrations for aloe vera gel, $0.1 \mathrm{ml}, 0.2 \mathrm{ml}$ and $0.5 \mathrm{ml}$ of the $100 \%$ gel were used while garlic extract $0.1 \mathrm{~g} / \mathrm{ml}, 0.25 \mathrm{~g} / \mathrm{ml}$ and $0.5 \mathrm{~g} / \mathrm{ml}$ of the freeze dried sample were used. The method of McCann et al., (1975b) was employed in the assay.

Counting of Revertant Colonies: After 48 hours of incubation, the plates used in each of the assays were scored and the revertant colonies of E. coli WP2 uvrA were counted using an automated colony counter. Plates with too many colonies were enumerated using the method of McCann et al, (1975a). Spontaneous mutation rate was determined by

\section{Number of colonies on plate
Number of cell plated $\frac{65}{\times 10^{3}}$}

\section{RESULTS}

The spontaneously reverting colonies of E. coli WP2 uvrA were determined in the Ames assay to have a spontaneous mutation rate of approximately $2.2 \times 10^{-7}$. This was obtained from the ratio of number of spontaneously reverting colonies to the number of cell initially plated out. Mutagenic activity of the acridine orange was higher at $100 \mu \mathrm{g} / \mathrm{ml}$ treated plates with $282 \times 10^{12}$ and lower at $50 \mu \mathrm{g} / / \mathrm{ml}$ treated plates with $154 \times 10^{12}$. This chemical is therefore a strong mutagenic and potentially carcinogenic substance.

The highest concentration of Aloe-vera gel used $(0.5 \mathrm{ml})$ showed $43.62 \%$ reduction on the effect of the mutagen on the bacteria reversion, as shown in the table 1. The two other concentration $0.2 \mathrm{ml}$ and $0.5 \mathrm{ml}$ of aloe vera showed $37.22 \%$ and $33.69 \%$ reduction in revertant of the bacteria colonies.

The garlic aqueous extract showed remarkable antimutagenic activity with a positive doseresponse relationship. $0.1 / \mathrm{ml}$ of garlic extract showed $72.16 \%$ reduction in the mutagenic effect of acridine on the bacterium while with $0.25 \mathrm{~g} / \mathrm{ml}$ of garlic extract the highest antimutgenic activity of the plant extract was obtained. It showed $81.02 \%$ reduction of the effect of acridine orange on the mutant strain of $E$. coli.

Table 1.

Effects of Treatment of Mutant Strain E. coli WP2 uvrA With Different Extracts and Acridine Orange

\begin{tabular}{|c|c|c|}
\hline Concentrates & $\begin{array}{l}\text { No. of } \\
\text { Colonies per } \\
\text { plant } \times 10^{12}\end{array}$ & Percentage \\
\hline Acridine $100 \mu \mathrm{g}$ & 282 & $333.8 \%$ increase \\
\hline $50 \mu \mathrm{g}$ & 154 & $136.9 \%$ increase \\
\hline $\begin{array}{l}\text { Aloe vera gel } \\
0.1 \mathrm{ml}\end{array}$ & 187 & $\begin{array}{l}33.69 \% \\
\text { reduction }\end{array}$ \\
\hline $0.2 \mathrm{ml}$ & 177 & 37.23 reduction \\
\hline $0.5 \mathrm{ml}$ & 159 & 43.62 reduction \\
\hline Garlic $0.1 \mathrm{~g} / \mathrm{ml}$ & 78.5 & 72.16 reduction \\
\hline $0.25 \mathrm{~g} / \mathrm{ml}$ & 71 & 74.82 reduction \\
\hline $0.5 \mathrm{~g} / \mathrm{ml}$ & 53.5 & 81.02 reduction \\
\hline
\end{tabular}

\section{DISCUSSIONS}

Spontaneous mutation of Escherichia coli WP2 uvrA was determined to have reverted spontaneous rate of approximately $2.2 \times 10^{-7}$. This shows that mutation of bacteria occurs naturally even when they are not exposed to a mutagen. However, the frequency is very low. The mutagenic activity of acridine orange dye on tryptophan auxotroph $E$. coli WP2 uvrA strain was 
evident in this study. The dye increased the mutation rate of the bacterial strain to $333.8 \%$ at $100 \mu \mathrm{g} / \mathrm{ml}$ concentration of the dye.

The antimutagenic activity of the plant extract used showed garlic extract to be strongly antimutagenic than aloe vera. The high degree of antimutgenicity of garlic extract is probably due to the wealth of organosulphur compounds it contains. Phytochemical constituents of garlic include ajoene, Allian allin, allycystein, diallylsulphide and over 100 other biologically useful secondary metabolites have been reported to be inherent in the valuable spice (Dorant, et al., 1993 and Belman, 1983).

The antimutagenicity implies that garlic may have potential anticarcinogenic effect on cancer induced by mutations of the critical genes of the cell cycle. The mechanisms by which garlic may reduce the risk of cancer may not solely be via reduction of mutation; but may involve the antioxidant activity, immune systems enhancing properties and high levels of tannins present in garlic which help reduce incidence of tumors (Chung et. al, 1998). Hence, the consumption of this plant spice may actually be giving protection to human body against mutation of cells and cancer induced processed food substances we consumed daily. Also, Aloe vera possesses some activity against mutagens which possibly can be enhanced at higher concentration

\section{REFERENCES}

Adetumbi, M.A. \& Lau, B.H. (1983). Allium sativum (garlic)-a natural antibiotic. Medical Hypothesis 12
(3): 227-237.

Ames, B.; Lee, F. \& Durston, W. (1973). An improved bacterial test system for detection and classification of mutagens and carcinogens. Proceedings of National Academy of Science, USA. 70: 782-786.

Belman, S. (1983). Onion and Garlic oil inhibit tumor production carcinogenesis 4 (8): 1063-6.

Chung, K. Y.; Wong, T.Y.; Wei, C.I.; Wang Huang, Y.W. \& Lin, Y. (1998). Tannins and human health: a review. Critical review Food Science Nutrition. 38 (6): 421-64.

Dorant, E.; Van den Barndt P.; Goldbohm, R.; Hermus, S. \& Turnans, F. (1993). Garlic and its significance for the prevention of cancer. British Journal for Cancer. 67: 424-9.

Haller, J. S. (1990). A drug for all seasons, medical and pharmalogical history of aloe.

Bulletin of New York Academy of Medicine. 66: 647659.

Maron, D.M. and Ames, B.N. (1983). Revised methods for the Salmonella mutagenicity test. Mutation Research 113:173-215.

McCann, J.; Spingarn, N.E.; Kobori, J. \& Ames, B.N. (1975a). Detection of carcinogens as mutagens: Bacterial tester strains with $\mathrm{R}$ factor plasmids. Proc. Natl. Acad. Sci. 72, 979-983.

McCann, J.; Choi, E.; Yamasaki, E. \& Ames, B.N. (1975b). Detection of carcinogens as mutagens in the salmonella/microsome test: Assay of 300 chemicals. Proc. Nat. Acad. Sci. 72(12):5135-5139.

Surh, Y. (1999). Molecular mechanisms of chemopreventive effects of selected dietary and medicinal phneolic substances. Mutation Research 428(1-2) 305-327.

Varmus, H. \& Weinberg, R.A. (1993). Genes and Biology of cancer. Scientific America Library. New York. 